\title{
THE EFFECTIVENESS OF AMNIOTIC MEMBRANE DEPENDING ON THE CAUSE OF CORNEAL DAMAGE IN DOGS
}

\author{
O. V. SHUPYK, Graduate Student \\ Department of Surgery and Pathophysiology \\ named after Academician I. O. Povazhenko \\ https://orcid.org/0000-0002-1081-3932
}

National University of Life and Environmental Sciences of Ukraine, Kyiv, Ukraine

E-mail:vethouse.avs@ukr.net

A. Y. MAZURKEVYCH, Doctor of Veterinary Sciences Professor

Department of Surgery and Pathophysiology

named after Academician I. O. Povazhenko

https://orcid.org/0000-0002-6217-5266

National University of Life and Environmental Sciences of Ukraine, Kyiv, Ukraine

E-mail:aymaz@ukr.net

R. R. ВОКОТКО, Candidate of Veterinary Sciences Assistant

Department of Surgery and Pathophysiology

named after Academician I. O. Povazhenko

https://orcid.org/0000-0002-6217-5266

National University of Life and Environmental Sciences of Ukraine

E-mail:bokotko28@gmail.com

T. L. SAVCHUK, Candidate of Veterinary Sciences, Senior Lecturer Professor

of Department of Surgery and Pathophysiology

named after Academician I. O. Povazhenko

https://orcid.org/0000-0002-7351-5684

National University of Life and Environmental Sciences of Ukraine

E-mail: t_sav4uk@ukr.net

O. S. PASNICHENKO, Candidate of Veterinary Sciences, Assistant

Department of Normal and Pathological morphology

and forensic veterinary medicine

https://orcid.org/0000-0003-5267-5289

Odessa State Agrarian University

E-mail: missKolbeshkina@gmail.com

Y. M. KRYSTYNIAK, Veterinarian

https://orcid.org/0000-00433-5265-5277

Kosiv

E-mail: kristinyak@gmail.com 
Abstract. The results of studies on clinical cases of keratitis in dogs of different etiology using measuring instruments and visual methods after amniotic membrane transplantation, which is the inner of the three amniotic membranes, transparent, avascular, developing from the fetal ectoderm and consisting of the epithelial layer, located on the main membrane and connective tissue stroma. These results make it possible to analyze and further study the effect of allogeneic mesenchymal stem cells during amniotic membrane transplantation for various defects of the eye in general, as well as corneas with ulcers of various etiologies.

Eye injuries and chemical burns are ophthalmic emergencies that require immediate diagnosis and treatment, as they can lead to deterioration and loss of vision. Clinical manifestations of such burns are caused by exacerbation of the innate immune response due to the infiltration of inflammatory cells and activation of stromal fibroblasts. New treatments are emerging that address restorative mechanisms that improve the surface of the eye after injury; for example, stem cell transplantation has been successfully reported for this purpose.

The main task of the study is to prove the effectiveness of the amniotic membrane to indicate activation of proliferation, stopping tissue apoptosis, reducing the activity of the inflammatory process, accelerating epithelialization and normalization of the corneal stroma, which leads to normal restoration of transparency without vascularization and turbidity.

Keywords: clinical cases of keratoconjunctivitis, dogs of different breeds, mesenchymal stem cells, amniotic membrane transplantation, corneal condition

\section{Introduction}

The use of the advances in biotechnology to increase the effectiveness of treatment of animals with different etiological pathogenicity is one of the most promising approaches to veterinary science and practice, especially the initiative results of experimental studies on the treatment of different animals through transplantation of mesenchymal stem cells, which have not been used before.

The use of mesenchymal (mesenchymal, stromal) stem cells in veterinary medicine for various eye pathologies in animals is based on a sufficient scientific and methodological basis. Developed methods for the selection of animal bone marrow and isolation from it of mononuclear cell fractions with high proliferative activity allow to obtain the required number of mesenchymal stem cells as soon as possible and use them to stimulate reparative processes in pathologically altered eye tissues.

The method of treatment is extremely relevant because it solves an urgent issue, which is extremely important at present, as eye diseases among animals occupy from 40 to $80 \%$ in all species of animals, namely in small ones.

\section{Analysis of recent researches and publications}

Among the pathologies of the organ of vision, the leading place is occupied by inflammatory diseases, traumatic eye injuries. According to the domestic literature, the share of eye injuries accounts for more than $10 \%$ in the structure of the entire pathology of the organ of vision, with burns accounting for $8 \%$. Of all eye injuries, the cornea accounts for up to $80 \%$ (Bothra \& Arumugam, 2018). 
Burns caused by various physical (thermal and radiation) and chemical (alkalis and acids) factors differ significantly in the mechanisms of eye tissue damage but have a similar clinical picture, mainly due to the severity of the damage (Colombo \& Melo, 2018).

Physiological regeneration of the anterior corneal epithelium is carried out by constant reproduction of cambial elements and their differentiation to the center by rapid migration from the periphery to the visual axis Complete renewal of the anterior epithelium occurs within 5-7 days. (Calitz, 2018; Gariani, 2017; Gryshchenko et al., 2019)

But only $2 \%$ of corneal epithelial basal cells have similar activity. Epithelial basal cells, being highly differentiated, are not capable of reproduction (Gryshchenko, 2018; Daniels et al., 2018).

There is also evidence that in some animals, corneal stem cells along with the limbus may be diffusely scattered throughout the corneal epithelium (Gula \& Margitich, 2000). According to most researchers, normal corneal epithelization is possible if at least half of the limbal area is preserved (Melnychuk, 2019; Sang-Chul, 2020). With complete limbal insufficiency, the epithelialization of a cornea is possible only due to the conjunctival epithelium (Solís-Calero, 2015; Starr et al., 2019).

Many studies have been performed on laboratory animals in the experiment and very little is known about the use of the amniotic membrane in clinical cases for dogs with different causes of injury. Therefore, studies in the direction of nosology of various eye pathologies in animals are very relevant today and require more extensive research in this area.

After severe injuries with the total destruction of the germinal zone of the limbus, pannus develops, and in this case, the cornea is always permeated with blood vessels (Tomchuk, 2019). In addition, limbal cell failure contributes to the development of corneal defects after burns (Udut, 2013; Vlizlo et al., 2012).

The purpose of the study: to determine the effectiveness of amniotic membrane transplantation for various injuries and pathologies of the cornea in spontaneous clinical cases, with the study of the regeneration of entire corneal epithelium.

\section{Materials and methods of research}

The experimental study was carried out on the eyes of dogs of different breeds, with spontaneous cases of different injuries with different degrees and complexity, using the same transplant material by the same technique.

Control studies were performed on days 10,20 , and 30 of the experiment. Surgical interventions were performed on the basis of the veterinary clinic of the Nemishaevo Agricultural College. All procedures provided for in the study protocol were performed in accordance with the requirements of the European Convention for the Protection of Pets and Laboratory Animals (the Convention was ratified by the Law of Ukraine, No 578-VII (578-18) of 18/09/2013).

Fig. 1 shows dog eyes with different injuries:

1.1 Deep purulent keratitis (with white purulent infiltrate and vascularization).

1.2 Keratomalacia of the cornea (after chemical burns, with immune-mediated complications).

1.3 Subtotal corneal sequestration (congenital).

1.4 Pannus and plasma of the third eyelid (complicated by ehrlichiosis). 


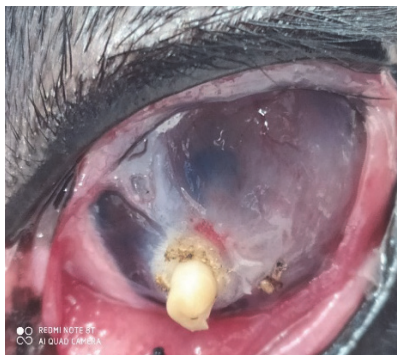

Fig. 1.1

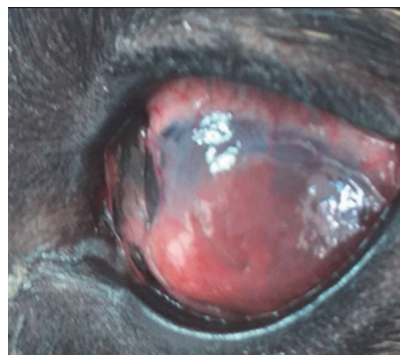

Fig. 1.4

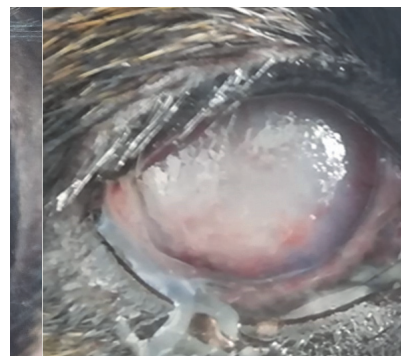

Fig. 1.2

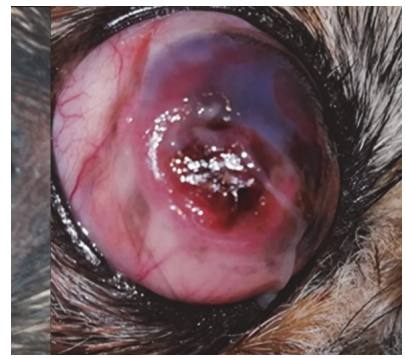

Fig. 1.5

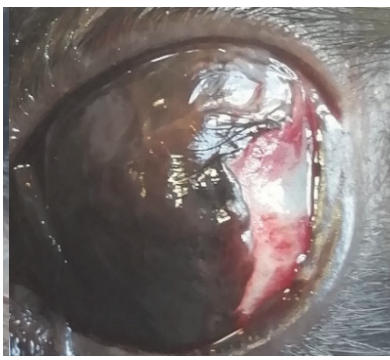

Fig. 1.3

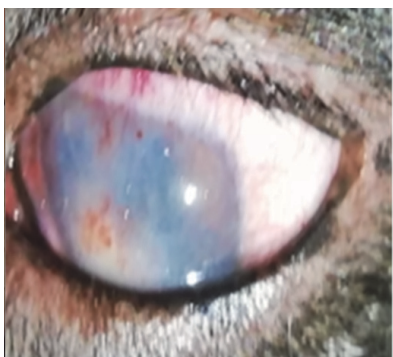

Fig. 1.6
1.5 Perforated septic corneal ulcer (as a result of mechanical trauma).

1.6 Herpesvirus epithelial dystrophy with pathological neovascularization of the cornea.

After surgical cleaning of the pathological tissues, the prepared amniotic membrane was sutured with a pursestring suture along the edge of the limbus (Polyamide 0007 thread), and the amniotic membrane extract was installed.

To assess the degree of inflammation and determine the extent of damage to

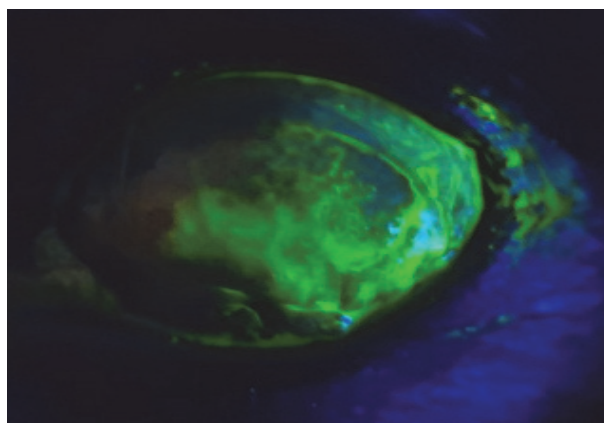

Fig. 2 the layers of the cornea, the following studies were used:

1. Fluorescein Seidel test (use of fluorescein dye, which indicates the degree of damage to the surface of the cornea). The degree of keratopathy was determined by the area and intensity of corneal staining with fluorescein. The cornea was divided into 5 segments (upper, lower, lateral, medial, and central), in each of which the degree of staining was assessed on a 3-point scale depending on the intensity of staining, where

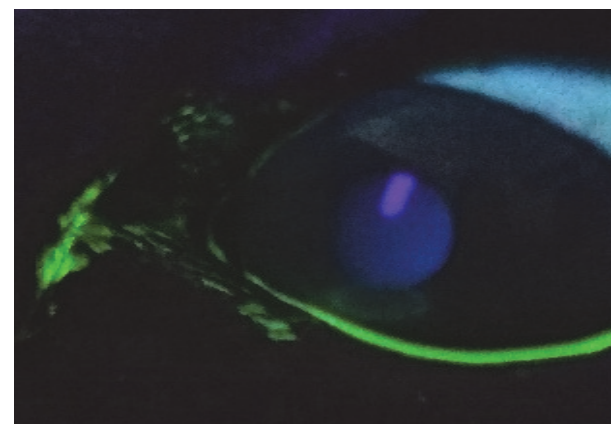

Fig. 3 
0 points - no staining, 1 point - slight staining, 2 points - moderate color, 3 points - pronounced color (Fig. 2-3).

2. Tonometry in a non-contact way using a Tonovet veterinary tonometer, the norm was taken as an average of 15-23 $\mathrm{mm} \mathrm{Hg}$, where 0 points - norm, 1 point -hypotension, 2 points - hypertension.

3. Evaluation by review according to the criteria (used the developed score scale). I. Isolation in the conjunctival cavity: 0 - absent, 1 - minor mucous, 2 - pronounced mucous; II. The degree of conjunctival hyperemia: 0 - pale pink, corresponds to the physiological norm, 1 - slight conjunctival hyperemia, 2 - moderate conjunctival hyperemia, 3 - severe conjunctival hyperemia; III. Corneal edema: 0 - no corneal edema, 1 - mild local corneal edema in the area of inflammation, 2 - moderate local corneal edema in the area of inflammation, 3 - diffuse edema in the area of inflammation with the transition to the surrounding cornea; IV. Inflammatory infiltration: 0 - absent, 1 - single (not more than three) subepithelial infiltrates, 2 multiple (more than three) subepithelial infiltrates, 3 - local drain infiltration of the cornea; V. Vascularization of the cornea: 0 - absent, 1 - is within one square, $2-$ is within two squares; VI. Condition of the surrounding cornea: 0 - transparent, no corneal edema, 1 - transparent, moderate corneal edema, 2 - decreased transparency, diffuse corneal edema;
VII. The state of the amniotic membrane: 0 - the membrane is completely lysed, 1 - the membrane is partially lysed, 2 - the membrane is preserved; VIII. Degree of corneal opacity: $0-a b$ sent, 1 - slight opacity, 2 - well-defined opacity, 3-opaque over the entire plane.

4. Schirmer's test (estimation of the amount of tear fluid using a test strip). A stopwatch was used. When evaluating the results, $\geq 15 \mathrm{~mm}$ ( 0 points) was considered the norm; from 5 to $10 \mathrm{~mm}$ - moderate insufficiency (1 point); $\leq 5$ $\mathrm{mm}$ - severe insufficiency of tear production (2 points), from 15 to $35 \mathrm{~mm}$ - pathological tearing (3 points).

The obtained results (digital material) were processed statistically using the Student's t criterion.

\section{Results of the research and their discussion}

In dogs, as a result of corneal injury and a long inflammatory process, there was purulent keratitis with white purulent infiltrate and vascularization. Fig. 1 shows the pathology at the time of the patient's admission to the clinic, Fig. 1a - the result in 10 days after suturing the amniotic membrane and installation of the extract from its tissues. In Fig. 1b after suturing of eyelids in 30 days, the restored transparent cornea with lobes of not completely lysed amnion tissues on edge of a limb is visible.

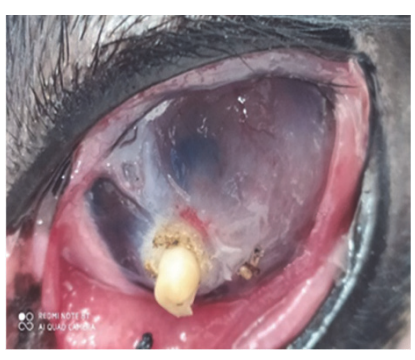

1

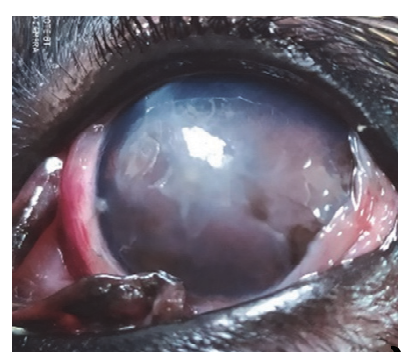

$1 \mathrm{a}$

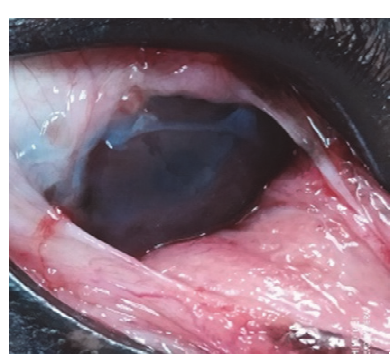

$1 b$ 


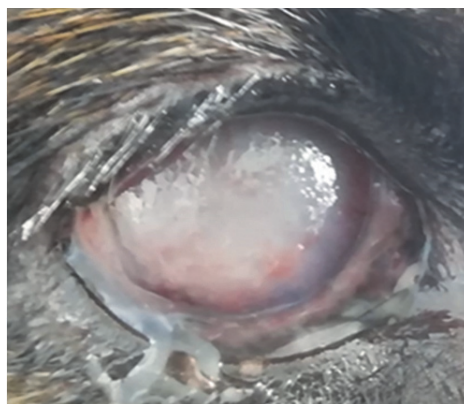

2

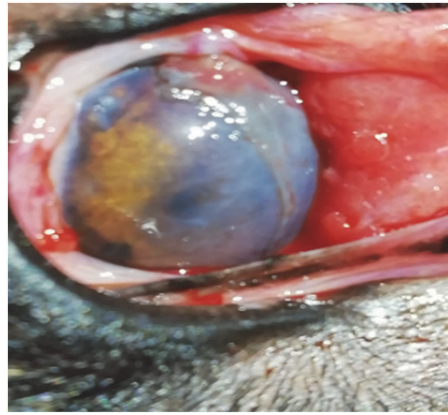

2b

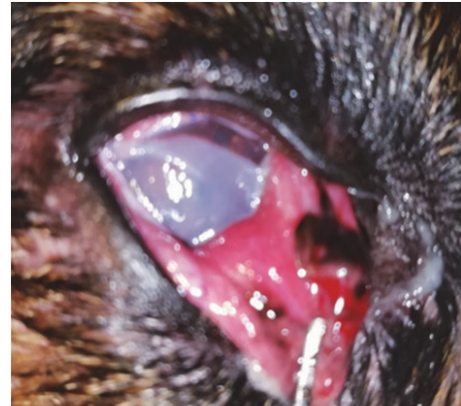

2a

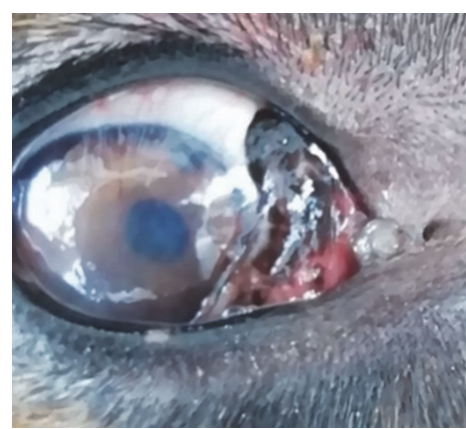

2c
In Fig. 2, a dog after chemical burns with immune-mediated complications, diagnosed with corneal keratomalacia. Surgical insertion was performed by the same method and in Fig. $2 \mathrm{a}$ and $2 \mathrm{~b}$ you can see the processes that occur on the $10^{\text {th }}$ and $20^{\text {th }}$ day after suturing the amniotic membrane. And on day 30, a completely restored cornea and a fully lysed amniotic graft are clearly visible (Fig. 2c).

In Fig. 3, a dog with recurrent pannus and plasma of the third eyelid is complicated by ehrlichiosis. Having performed the operation with transplantation of the prepared amnion according to the developed method in 10 days, as can be seen from Fig. 3a, the area of corneal impression decreases and by 20 days it is completely restored, but with some corneal vascularization (Fig. 3c). And on the $30^{\text {th }}$ day, the cornea was restored almost over the entire surface of the cornea, with parts of non-lysed amnion along the edge of the limbus (Fig. 3c).

In Fig. 4, the dog was diagnosed with progressive, congenital subtotal corneal sequestration, and after surgical examination, an amnion transplant was installed (Fig. 4a), and as can be seen from Photo $4 b$ and $4 c$, there are areas with completely transparent and restored layers of the cornea, and other vascularized ones require re-scaring and transplantation.

As a result of mechanical eye injury in Fig. 5, a perforated septic corneal ulcer was formed. After transplantation of the prepared amniotic membrane in 10 days, Photo 5a shows the active process of cleansing from the depth of the ulcer and non-lysed amnion, and within 20 days - its complete lysis with complete 
О. В. Шупик, А. Й. Мазуркевич, Р. Р. Бокотько, Т. Л. Савчук, О. С. Пасніченко,

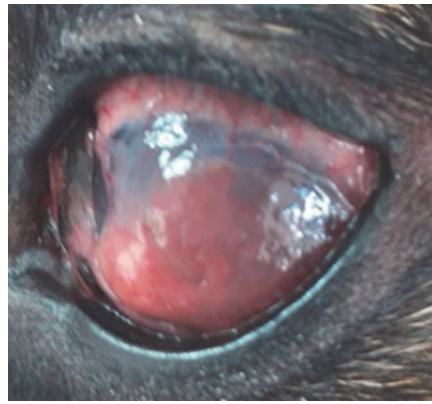

3

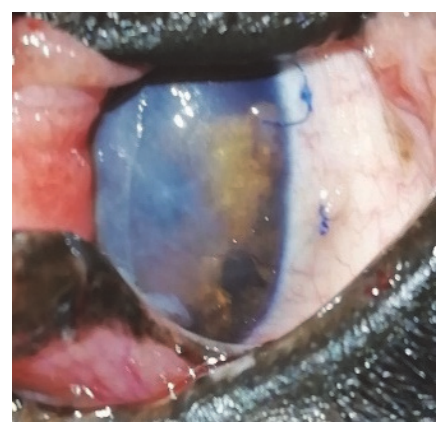

3b

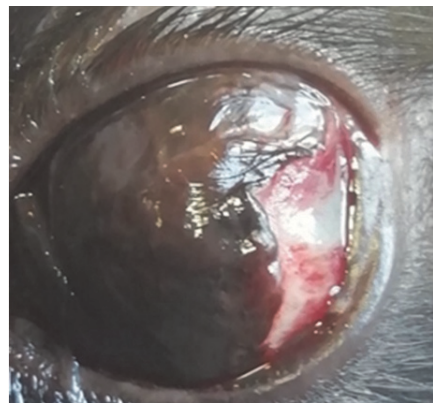

4

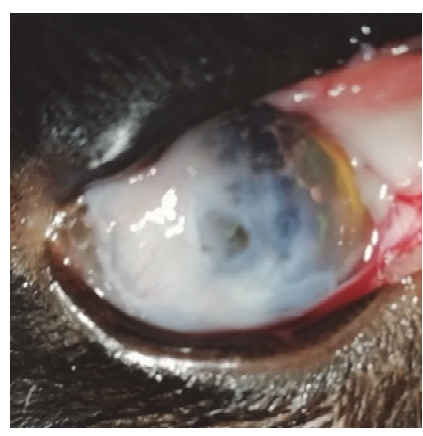

$4 b$

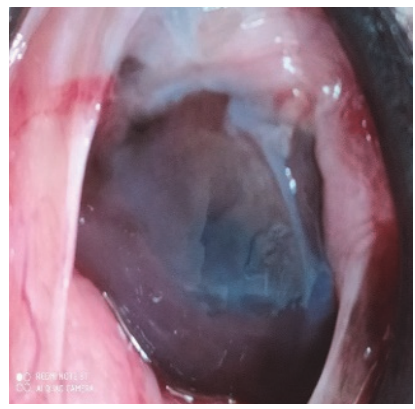

3a

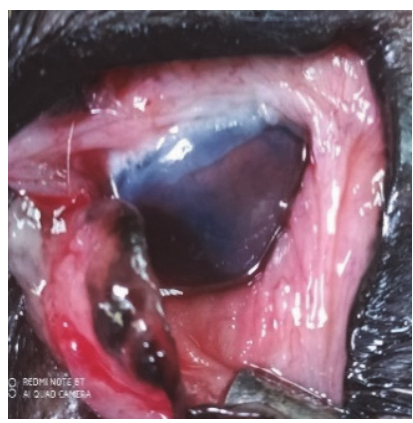

$3 \mathbf{c}$

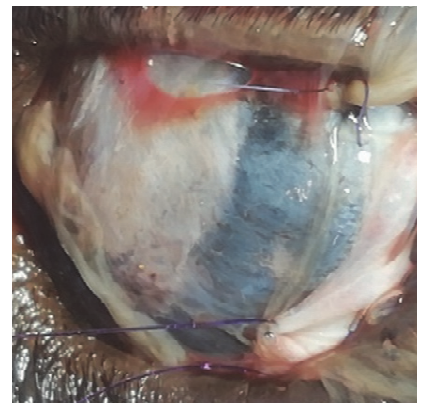

$4 a$

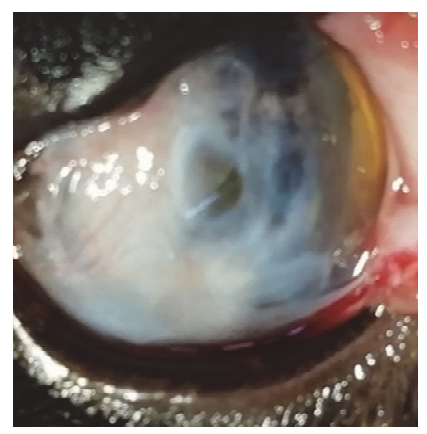

$4 \mathrm{c}$ 
healing of the ulcer and slight vascularization. On the $30^{\text {th }}$ day, you can see a completely restored cornea with a slight opacity in the area of damaged deep layers of the cornea.

In Fig. 6 - a patient with herpesvirus epithelial dystrophy that caused pathological neovascularization of the cornea. In this case, only installations of amniotic membrane tissue extract using eye films were used (Fig. 6a), and already on the $20^{\text {th }}$ and $30^{\text {th }}$ day the restored surface of the cornea is visible, with almost no visible signs of vascularization.

Table 1 shows the results of the assessment of the state of damage by the evaluation criteria according to the developed scale for each study and summarized in one numerical indicator for each patient with different clinical diagnoses and different etiology of corneal damage in dogs.

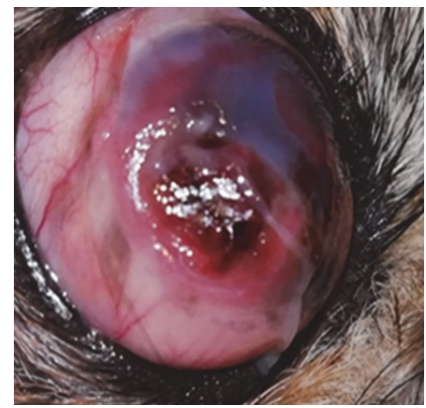

5

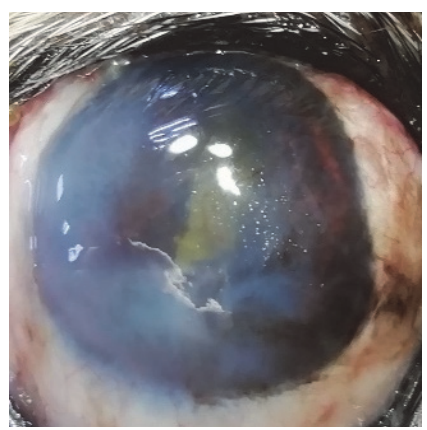

$5 \mathbf{b}$
10 days after amniotic membrane suturing in five cases out of six criteria, there were improvements by $50 \%$, inflammatory tissue infiltration decreased, stroma edema decreased, clinical manifestations decreased, and only in congenital pathology no significant changes occurred, only postoperative corneal stroma edema increased (Table 2).

On the $20^{\text {th }}$ day after amniotic membrane transplantation, again in five clinical cases out of six, the results according to the criteria in total significantly improved, there was a significant reduction in the inflammatory process, both in the conjunctiva and in the stroma of the cornea (Table 3). Significant lysis of the amniotic membrane was visible in all cases, which was noticeable only in the limbus area. In all cases, there was a slight vascularization and opacity of the almost

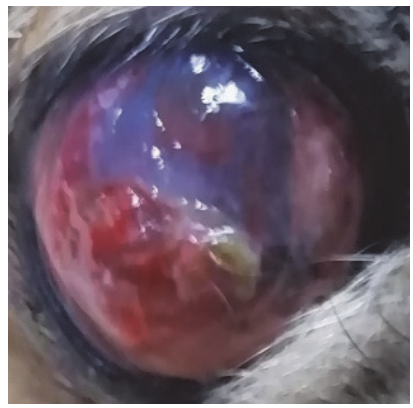

$5 \mathbf{a}$

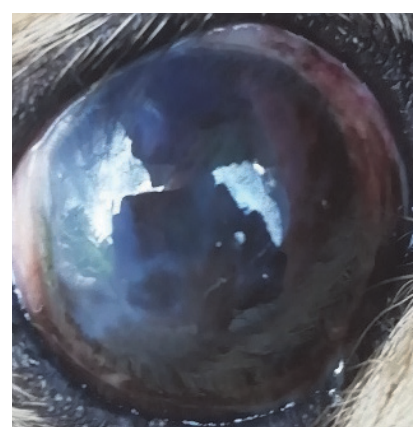

5c 


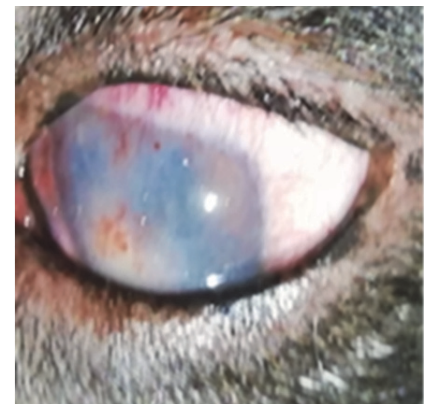

6

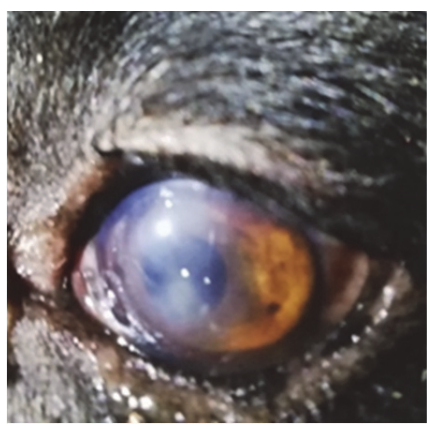

6b

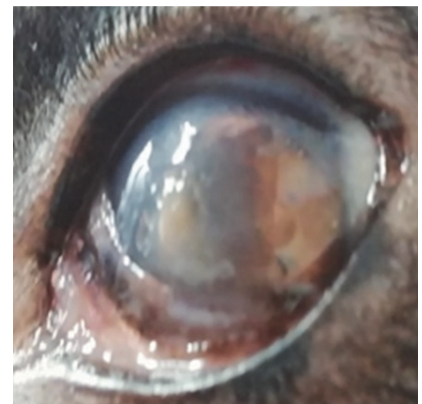

6a

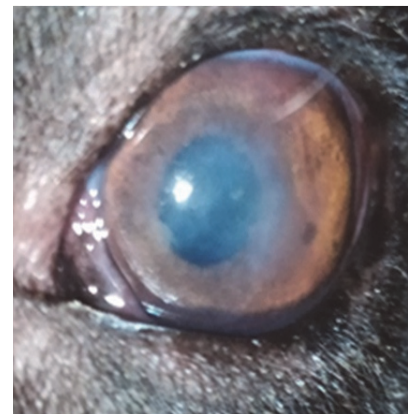

6c

\section{Assessment of the state of damage according to the criteria (on a scale) in the intact eye}

\begin{tabular}{|l|c|c|c|c|c|c|}
\hline \multicolumn{7}{|c|}{ Dogs with various corneal injuries } \\
\hline Evaluation criteria & 1.1 & 1.2 & 1.3 & 1.4 & 1.5 & 1.6 \\
\hline Fluorescein test (FT) & 2 & 3 & 3 & 0 & 3 & 1 \\
\hline Tonometry (T) & 1 & 2 & 2 & 0 & 2 & 0 \\
\hline Discharge in the conjunctival cavity (TYPE) & 2 & 2 & 2 & 0 & 2 & 2 \\
\hline Corneal stroma edema (NAB-C) & 3 & 2 & 2 & 1 & 3 & 2 \\
\hline Inflammatory infiltration (INF) & 3 & 2 & 3 & 0 & 2 & 2 \\
\hline Condition of the conjunctiva (CC) & 2 & 3 & 2 & 0 & 1 & 1 \\
\hline Condition of the surrounding cornea (CORN) & 2 & 2 & 2 & 0 & 2 & 2 \\
\hline Amniotic membrane (AM) condition & - & - & - & - & - & - \\
\hline Corneal opacity (OPAC) & 2 & 3 & 3 & 3 & 3 & 2 \\
\hline Corneal vascularization (VAS) & 2 & 3 & 3 & 0 & 2 & 2 \\
\hline Schirmer's test (SHT) & 3 & 3 & 2 & 0 & 3 & 2 \\
\hline The sum of evaluation criteria & 22 & 25 & 24 & 4 & 23 & 15 \\
\hline
\end{tabular}

restored corneal epithelial layer, but almost unchanged with the case of congenital pathology.
On day 30, all patients had no epiphora, the mucous membranes were pale pink (Table 4). The amniotic membrane 


\section{Assessment of the state of damage according to the criteria (on a scale) on day 10}

\begin{tabular}{|l|c|c|c|c|c|c|}
\hline \multicolumn{7}{|c|}{ Dogs with various corneal injuries } \\
\hline Evaluation criteria & 1.1 & 1.2 & 1.3 & 1.4 & 1.5 & 1.6 \\
\hline Fluorescein test (FT) & - & - & - & - & - & - \\
\hline Tonometry (T) & 0 & 2 & 2 & 0 & 2 & 0 \\
\hline Discharge in the conjunctival cavity (TYPE) & 1 & 1 & 1 & 0 & 1 & 1 \\
\hline Corneal stroma edema (NAB-C) & 2 & 1 & 1 & 1 & 2 & 1 \\
\hline Inflammatory infiltration (INF) & 2 & 1 & 2 & 0 & 1 & 1 \\
\hline Condition of the conjunctiva (CC) & 1 & 2 & 1 & 0 & 0 & 0 \\
\hline Condition of the surrounding cornea (CORN) & 1 & 1 & 1 & 1 & 1 & 1 \\
\hline Amniotic membrane (AM) condition & 2 & 2 & 2 & 2 & 2 & 0 \\
\hline Corneal opacity (OPAC) & 1 & 2 & 2 & 1 & 2 & 1 \\
\hline Corneal vascularization (VAS) & 1 & 2 & 2 & 0 & 1 & 1 \\
\hline Schirmer's test (SHT) & 2 & 2 & 1 & 0 & 2 & 1 \\
\hline The sum of evaluation criteria & 13 & 16 & 15 & 6 & 14 & 7 \\
\hline
\end{tabular}

was completely lysed, the integumentary epithelium of the cornea was not stained according to Seidel's test, which indicates the restoration of the morphological structure without damage in six cases, but in two cases a slight residual opacity was observed, and in two others - he phenomenon of partial infiltration along the limb with minor nodules suture, and no changes were observed with the case of congenital pathology, but the place of transparency of the corneal epithelial layer was clearly expressed, in contrast to the initial acanthosis, corneal sequestration, which is well expressed in Photo 1.4 and Table 5 in the column under the same number.

3. Assessment of the state of damage according to the criteria (on a scale) on day 20

\begin{tabular}{|l|c|c|c|c|c|c|}
\hline \multicolumn{7}{|c|}{ Dogs with various corneal injuries } \\
\hline Evaluation criteria & 1.1 & 1.2 & 1.3 & 1.4 & 1.5 & 1.6 \\
\hline Fluorescein test (FT) & - & - & - & - & - & - \\
\hline Tonometry (T) & 0 & 0 & 0 & 0 & 0 & 0 \\
\hline Discharge in the conjunctival cavity (TYPE) & 0 & 1 & 1 & 0 & 0 & 0 \\
\hline Corneal stroma edema (NAB-C) & 1 & 0 & 0 & 1 & 1 & 0 \\
\hline Inflammatory infiltration (INF) & 1 & 0 & 1 & 0 & 0 & 0 \\
\hline Condition of the conjunctiva (CC) & 1 & 2 & 1 & 0 & 0 & 0 \\
\hline Condition of the surrounding cornea (CORN) & 1 & 1 & 1 & 1 & 1 & 1 \\
\hline Amniotic membrane (AM) condition & 1 & 1 & 1 & 0 & 0 & 0 \\
\hline Corneal opacity (OPAC) & 1 & 2 & 2 & 2 & 2 & 1 \\
\hline Corneal vascularization (VAS) & 0 & 1 & 1 & 1 & 0 & 0 \\
\hline Schirmer's test (SHT) & 1 & 1 & 1 & 0 & 2 & 0 \\
\hline The sum of evaluation criteria & 7 & 9 & 9 & 5 & 6 & 2 \\
\hline
\end{tabular}




\section{Assessment of the state of damage according to the criteria (on a scale) on day 30}

\begin{tabular}{|l|c|c|c|c|c|c|}
\hline \multicolumn{7}{|c|}{ Dogs with various corneal injuries } \\
\hline Evaluation criteria & 1.1 & 1.2 & 1.3 & 1.4 & 1.5 & 1.6 \\
\hline Fluorescein test (FT) & 0 & 0 & 0 & 0 & 0 & 0 \\
\hline Tonometry (T) & 0 & 0 & 0 & 0 & 0 & 0 \\
\hline Discharge in the conjunctival cavity (TYPE) & 0 & 0 & 1 & 0 & 0 & 0 \\
\hline Corneal stroma edema (NAB-C) & 0 & 0 & 0 & 1 & 0 & 0 \\
\hline Inflammatory infiltration (INF) & 0 & 0 & 0 & 0 & 0 & 0 \\
\hline Condition of the conjunctiva (CC) & 0 & 1 & 1 & 0 & 0 & 0 \\
\hline Condition of the surrounding cornea (CORN) & 0 & 0 & 0 & 1 & 0 & 0 \\
\hline Amniotic membrane (AM) condition & 0 & 0 & 0 & 0 & 0 & 0 \\
\hline Corneal opacity (OPAC) & 1 & 1 & 0 & 2 & 1 & 0 \\
\hline Corneal vascularization (VAS) & 0 & 0 & 0 & 1 & 0 & 0 \\
\hline Schirmer's test (SHT) & 0 & 0 & 1 & 0 & 0 & 0 \\
\hline The sum of evaluation criteria & 1 & 2 & 3 & 5 & 1 & 0 \\
\hline
\end{tabular}

\section{Summary information on the sums of evaluation criteria}

\begin{tabular}{|l|c|c|c|c|c|c|}
\hline \multicolumn{7}{|c|}{ Dogs with various corneal injuries } \\
\hline The sum of evaluation criteria & 1.1 & 1.2 & 1.3 & 1.4 & 1.5 & 1.6 \\
\hline For the period of pathology & 22 & 25 & 24 & 4 & 23 & 15 \\
\hline 10 days after & 13 & 16 & 15 & 6 & 14 & 7 \\
\hline 20 days after & 7 & 9 & 9 & 5 & 6 & 2 \\
\hline 30 days after & 1 & 2 & 3 & 5 & 1 & 0 \\
\hline
\end{tabular}

\section{Conclusions and future perspectives}

It is established that after amniotic membrane transplantation for eye injuries of different genesis, proliferation processes are activated, tissue apoptosis processes are stopped, inflammatory process activity is reduced, which accelerates corneal stromal epithelialization and normalization, which causes a normal restoration of transparency without vascularization and opacity.

\section{References}

Bothra, A., Arumugam, P., Panchal, V., Menon, D., Srivastava, S., Shankaran, D., ... \& Rao, V.
(2018). Phospholipid homeostasis, membrane tenacity and survival of Mtb in lipid rich conditions is determined by MmpL11 function. Scientific reports, 8(1), 1-14. doi: 10.1038/s41598-018-26710-z

Calitz, C., Hamman, J. H., Fey, S. J., Wrzesinski, K., \& Gouws, C. (2018). Use of corneal regeneration stimulants for traumatic injuries. Clinical ophthalmology. Toxicology mechanisms and methods, 28(5), 369-385. doi: 10.1080/15376516.2017.1422580

Colombo, S., Melo, T., Martínez-López, M., Carrasco, M.J., Domingues, M. R., Pérez-Sala, D., \& Domingues, P. (2018). Phospholipidome of endothelial cells shows a different adaptation response upon oxidative, glycative and lipoxidative stress. Scientific 
reports, 8(1), 1-13. doi: 10.1016/j.freeradbiomed.2018.04.297

Gariani, K., Ryu, D., Menzies, K. J., Yi, H.-S., Stein, S., Zhang, H., ... \& Auwerx1, J. (2017). Morphofunctional characteristics of reparative histogenesis in the cornea of rabbits with burn damage to the limbal region. Bulletin of Orenburg State University, 66(1), 132-141.

Gryshchenko, V. A. (2019). Blood and acid composition of blood and biles in calves at enteropatology and application of milk phospholipides. Ukrainian Journal of Veterinary Sciences, 10(4), 36-42. doi: 10.31548/ ujvs2019.04.005

Gryshchenko, V., Danchenko, O., \& Musiychuk, V. (2019). Modification of modeling methodof toxic dystrophy of liver in rats. In: Nadykto V. (eds). Modern Development Paths of Agricultural Production. Springer, Cham. doi: 10.1007/978-3-030-14918-5_67

Gryshchenko, V. A., Sysolyatin, S. V., \& Gulevata, J. V. (2018). Phospholipid composition of blood plasma and internal organs of rats with diclofenac-induced hepatitis. Ukrainian Journal of Ecology, 8(3), 211-215. Gryshchenko, V., Sysolyatin, S., \& Midyk, S. (2019). Fatty acids of lipids of blood serum and liver of rats with tetracyclin-induced hepatosis and at correction, 10(4), 520525. doi: 10.15421/021976

Gula, N. M., \& Margitich, V. M. (2009). Zhyrni kysloty ta yikh pokhidni pry patolohichnykh stanakh [Fatty acids and their derivatives in pathologic starts]. Kyiv: Naukova dumka.

Melnychuk, D. O., Gryshchenko, V. A., \& Lytvynenko, O. N. (2009). Patent UA, 86516. Veterynarna biologichno aktyvna dobavka liposomal'noi' formy ta sposib reparatyvnoi' terapii' $v$ gepatologii' [Veterinary biologically active additive of liposomal form and method of reparative therapy in hepatology]. Ukrainian Intellectual Property Institute, Kyiv.

Sang-Chul, K., \& Xuemin, W. (2020). Features of healing of severe alkaline burns only of the cornea, only of the limbal zone, as well as their combination in the experiment. Ophthalmology. EBC20190089. doi: 10.1042/ EBC20190089

Solís-Calero, C., Ortega-Castro, J., Frau, J., \& Muñoz, F. (2015). Nonenzymatic reactions above phospholipid surfaces of biological membranes: reactivity of phospholipids and their oxidation derivatives. Oxidative Medicine and Cellular Longevity, 319505:22. doi: 10.1155/2015/319505

Starr, M. L., Sparks, R. P., Arango, A. S., Hurst, L. R., Zhao, Z., Lihan, M., ... \& Fratti, R. A. (2019). Outcomes and DNA analysis of ex vivo expanded stem cell allograft for ocular surface reconstruction. Ophthalmology. Journal of Biological Chemistry, 294, 31003116. doi: 10.1074/jbc.RA118.006552

Tomchuk, V., Gryshchenko, V., Vlizlo, V., \& Enciu, V. (2019). Corrective effect of milk phospholipids in pathological conditions. Iaşi Editura Ion Ionescu de la Brad.

Udut, V. V., Vengerovsky, A. I., \& Dygai, A. M. (2013). Effects of phospholipid hepatoprotectors on apoptosis during experimental liver pathology induced by isoniazid and paracetamol. Bulletin of Experimental Biology and Medicine, 154(5), 614-617. doi: 10.1007/s10517-013-2012-9

Vlizlo, V. V., Fedoruk, R. S., \& Ratych, I. B. (2012). Laboratorni metody doslidzhen u biolohiyi, tvarynnytstvi ta veterynarniy medytsyni [Laboratory methods of investigation in biology, stock-breeding and veterinary]. Spolom, Lviv.

Yang, K. J., Son, J., Jung, S. Y., Yi, G., Yoo, J., Kim, D. K., \& Koo, H. (2018). Comparison of prognostic value of Roper Hall and Dua classification systems in acute ocular burns. British Journal of Ophthalmology, 171(7), 133-143. doi: 10.1016/j.biomaterials.2018.04.038

Zhang, X., Yang, L., Liu, Y., Song, Z., Zhao, J., Chen, D., ... \& Zhang, L. W. (2018). Liand limbal stem cell transplantation: new progresses and challenges. Ophthalmology and Applied Pharmacology, 348, 54-66. doi: 10.1016/j.taap.2018.04.016 


\section{О. В. Шупик, А. Й. Мазуркевич, Р. Р. Бокотько, Т. Л. Савчук, О. С. Пасніченко,} Ю. М. КрИСТИНяК (2020). ЕФЕКТИВНІСТЬ ЗАСТОСУВАННЯ АМНІОТИЧНОЇОБОЛОНКИ В ЗАЛЕЖНОСТІ ВІД ПРИЧИНИ УШКОДЖЕННЯ РОГІВКИ У СОБАК. Ukrainian Journal of Veterinary Sciences, 11(4): 48-60, https://doi.org/10.31548/ujvs2020.04.006

Анотація. Висвітлено результати досліджень кератиту в собак різної етіології в клінічних випадках за допомогою вимірювальних приладів та візуальних методів після трансплантації амніотичної мембрани. Вона є внутрішньою з трьох плодових оболонок, прозора, аваскулярна, розвивається з фетальної ектодерми і складається із шару епітеліальних клітин, розташованих на основній мембрані, і сполучнотканинної строми. Ці результати досліджень дають можливість аналізувати та в подальшому вивчати вплив алогенних мезенхімальних стовбурових клітин під час трансплантації амніотичної оболонки за різних дефектів ока загалом, а також рогівки з виразками різної етіології.

Серед патологій органу зору провідне місце займають запальні захворювання та травматичні пошкодження очей. За даними вітчизняної літератури, на частку травм ока припадає понад 10\% в структурі всіх патологій органу зору, водночас, опіки становлять 8\%. 3 усіх пошкоджень очей на частку рогівки припадає до 80\%. Опіки, спричинені різними фізичними (термічними й радіаційними) і хімічними (лугами й кислотами) факторами, значно різняться механізмами пошкодження тканин ока, але мають подібну клінічну картину, зумовлену в основному тяжкістю пошкодження.

Фізіологічна регенерація переднього епітелію рогівки здійснюється постійним розмноженням камбіальних елементів і їхнім диференціюванням до центру, стрімкою міграцією від периферіїдо зорової осі. Повне оновлення переднього епітелію відбувається впродовж 5-7 діб.

Основне завдання дослідження - довести ефективність застосування амніотичної оболонки, щоби вказувало на активізацію процесів проліфрерації, зупинку прочесів апоптозу тканин, зменшення активності запального процесу, що прискорює епітелізацію і нормалізацію строми рогівки, що й зумовлює нормальне відновлення прозорості без васкуляризації та помутнінь.

Ключові слова: клінічні випадки кератоконююнктивіту, собаки різних порід, мезенхімальні стовбурові клітини, трансплантація амніотичної оболонки, стан рогівки 